\title{
Structure, Function, and Expression of Drosophila melanogaster FMRFamide-related Peptides
}

\author{
R. NICHOLS, ${ }^{a, b, c}$ J. B. McCORMICK, ${ }^{a}$ AND I. A. LIM ${ }^{b}$ \\ ${ }^{a}$ Biological Chemistry Department and \\ ${ }^{b}$ Undergraduate Research Program, University of Michigan, \\ Ann Arbor, Michigan 48109-1048
}

\begin{abstract}
In 1977, Price and Greenberg ${ }^{1}$ identified the tetrapeptide FMRFamide as a cardioexcitatory molecule from mollusc. Subsequent to this discovery, FMRFamide-related peptides (FaRPs) have been identified in both invertebrates and vertebrates. 2,3 Peptides in the FaRP family contain a common RFamide C-terminus and act as modulators and messengers of neural and gastrointestinal functions. ${ }^{2,3}$ Like other organisms, Drosophila melanogaster contains several genes ${ }^{4-6}$ that encode for numerous FaRPs. ${ }^{7,8}$ Elucidating the processing and activities of multiple FaRPs encoded in a single precursor is critical to establishing their roles in physiology. In this manuscript, we describe the distribution of FMRFamide immunoreactive materials in the Drosophila central nervous system and gut, and correlate it with the expression of specific FaRPs and their activities. The unique distributions ${ }^{9-13}$ and biological activities $^{14,15}$ of Drosophila FaRPs suggest that the precursors are highly processed and the structurally related peptides are not functionally redundant. The complete distribution of FaRPs in the central nervous system and gut as detected by FMRFamide antisera is not accounted for by the sum of the individual expression patterns of the known Drosophila peptides. Thus, these data suggest that one or more Drosophila FaRPs or structurally related peptides remain to be discovered.
\end{abstract}

\section{INTRODUCTION}

Peptides that play critical roles in physiology can frequently be grouped together based on structure. One peptide family has a common C-terminal RFamide, but distinct $\mathrm{N}$-terminal extensions. The first member of this group to be isolated was FMRFamide, a molluscan cardioexcitatory molecule. ${ }^{1}$ Subsequent to this discovery, antisera to FMRFamide have been used to identify FMRFamide-related peptides (FaRPs) from numerous organisms. ${ }^{2,3}$ The conservation of structure, function, distribution, and abundance of FaRPs suggests that they play important roles in physiology.

Organisms have more than one gene encoding multiple FMRFamide-related peptides. ${ }^{4-7}$ Thus, in order to understand the signal transduction processes associat-

${ }^{c}$ Address for correspondence: R. Nichols, 830 North University Avenue, Ann Arbor, MI 48109-1048. Phone: 734/764-4467; fax: 734/647-0884.

e-mail: nicholsr@umich.edu 
ed with these important messengers, it is crucial to elucidate their regulation of expression. To this end, we are studying the distribution and processing of FaRP gene products in Drosophila melanogaster. ${ }^{9-13}$ Three Drosophila genes, dromyosuppressin (Dms), ${ }^{7}$ drosulfakinin (Dsk), ${ }^{5}$ and FMRFamide, ${ }^{4,6}$ encode several FaRPs. We have isolated TDVDHVFLRFamide, ${ }^{6}$ FDDY(SO3H)GHMRFamide, ${ }^{7}$ and DPKQDFMRFamide, SDNFMRFamide, and TPAEDFMRFamide ${ }^{6}$ contained in Dms, Dsk, and FMRFamide in Drosophila, respectively. We have raised peptidespecific antisera and reported the expression patterns of the individual Drosophila FaRPs. ${ }^{9-13}$ Here, we use antisera to FMRFamide to identify the family of structurally related peptides, thus providing a complete map of FaRP immunoreactive materials in the Drosophila central nervous system and gastrointestinal tissue. Taken together, the expression patterns of all of the known individual FaRPs do not account for the complete pattern of FMRFamide antisera staining. Therefore, these data suggest that at least one other structurally related peptide remains to be identified in Drosophila.

\section{MATERIALS AND METHODS}

Immunolocalization was performed as previously described. ${ }^{15-17}$ Briefly, tissue was dissected in $\mathrm{Ca}^{++}$-free Ringer's solution $(130 \mathrm{mM} \mathrm{NaCl}, 4.7 \mathrm{mM} \mathrm{KCl}$, $1.8 \mathrm{mM} \mathrm{MgCl}_{2}, 0.74 \mathrm{mM} \mathrm{Na}_{2} \mathrm{HPO}_{4}, \mathrm{pH} 7$ ) and fixed in $4 \%$ paraformaldehyde for 4-6 hours at $4{ }^{\circ} \mathrm{C}$. After a thorough wash in PTN $\left(0.1 \mathrm{mM} \mathrm{NaPO}_{4}, 0.3 \%\right.$ Triton X$100,0.1 \%$ NaAzide, $0.1 \%$ BSA), the tissue was incubated in 1:500 FMRFamide antisera (Peninsula Labs) overnight at $4{ }^{\circ} \mathrm{C}$ with a slow rotatory motion, rinsed in PTN, and then placed in goat anti-rabbit FITC-conjugated second antibody (Sigma Chemical Co.) or Cy3-conjugated second antibody (Jackson ImmunoResearch Labs, Inc.) for 4-6 hours at $4^{\circ} \mathrm{C}$. After extensive washing in PTN, the tissue was rinsed in $4 \mathrm{mM} \mathrm{NaCarbonate,} \mathrm{pH} 9$, before being mounted in $80 \%$ glycerol containing 5\% propyl gallate under a glass coverslip.

Data were collected on a BioRad $600 \mathrm{Kr}$-Ar laser confocal attached to a Nikon inverted microscope using a $20 \times$ or $40 \times$ objective. Optical sections or $\mathrm{z}$ series were collected using the CoMOS program. Adobe photoshop software, version 3.0, was used to process the data, and images were made with a Kodak XLS8600 printer.

Immunoreactivity was observed bilaterally symmetric to the midline in the nervous system; thus, reference to one cell indicates the presence of a pair of cells positioned bilaterally symmetric to one another. The positions of the corresponding cells were not always perfectly symmetrical due to the distortion of the tissue that can be caused by placing a coverslip on it.

\section{RESULTS AND DISCUSSION}

The presence of FMRFamide immunoreactive material in the Drosophila central nervous system is represented by the staining of larval neural tissue (FIGURE 1). Signal is observed in the brain lobes as well as the subesophageal ganglion and ventral nerve cord. In addition to the numerous cells stained by FMRFamide antisera, two immunoreactive fibers were observed to project away from the ventral nerve cord. 


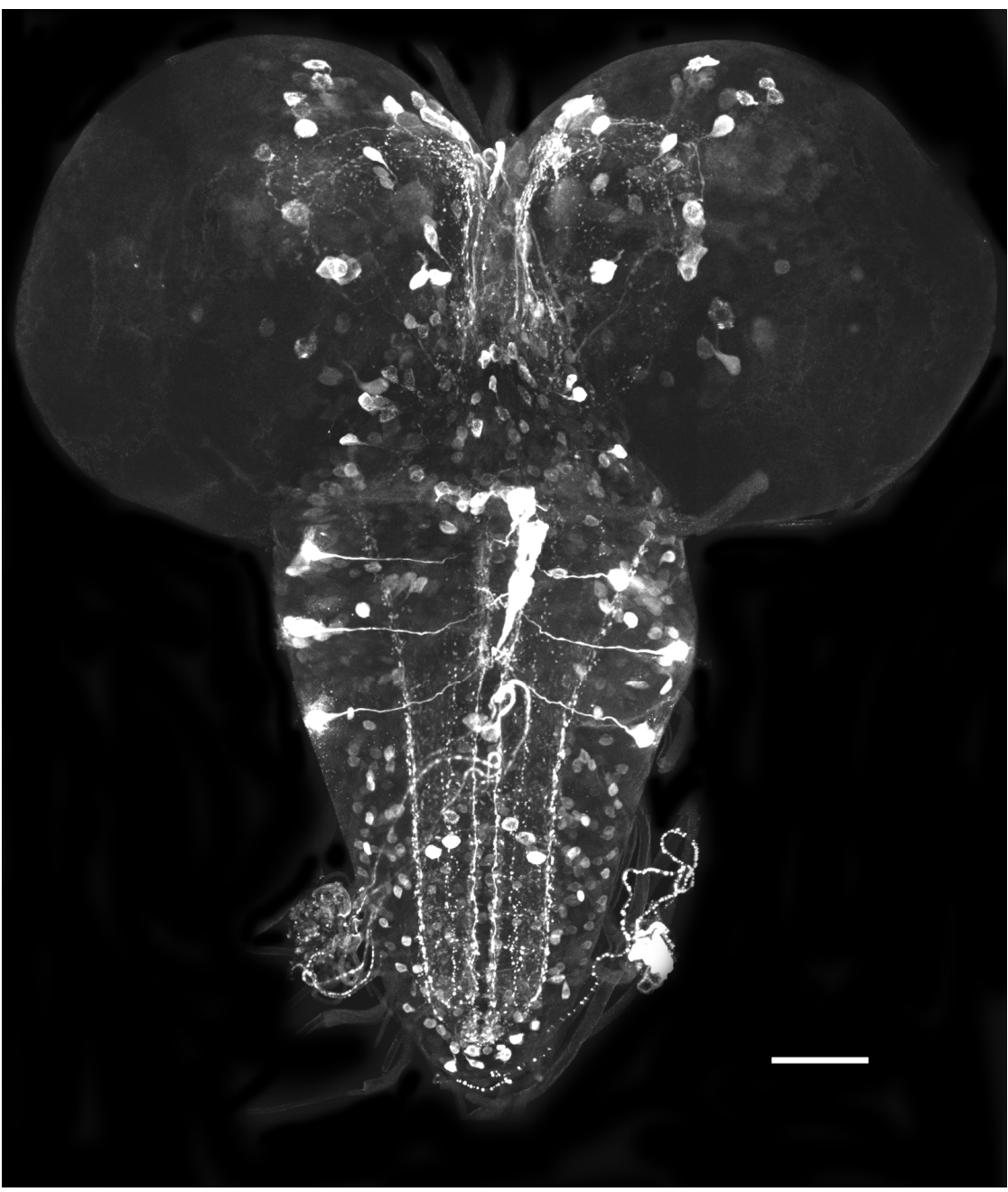

FIGURE 1. FMRFamide antisera staining in the Drosophila larval central nervous system. Rabbit FMRFamide antisera (Peninsula) and goat anti-rabbit FITC-labeled second antibody (Sigma) or Cy3-labeled second antibody (Jackson) were used to stain neural tissue prepared as a whole mount. The bar in the lower right-hand corner represents 50 microns.

One immunoreactive fiber extended from the third thoracic ganglion, while the other projected from the posterior abdominal ganglion. The site or sites innervated by these fibers were not identified.

The overall pattern of FMRFamide immunoreactive material found by staining with antisera to FMRFamide contains more cells than the combined expression patterns of individual FaRPs established using peptide-specific antisera. ${ }^{9-13}$ This is ascertained by comparing the distribution of FMRFamide antisera staining with the 

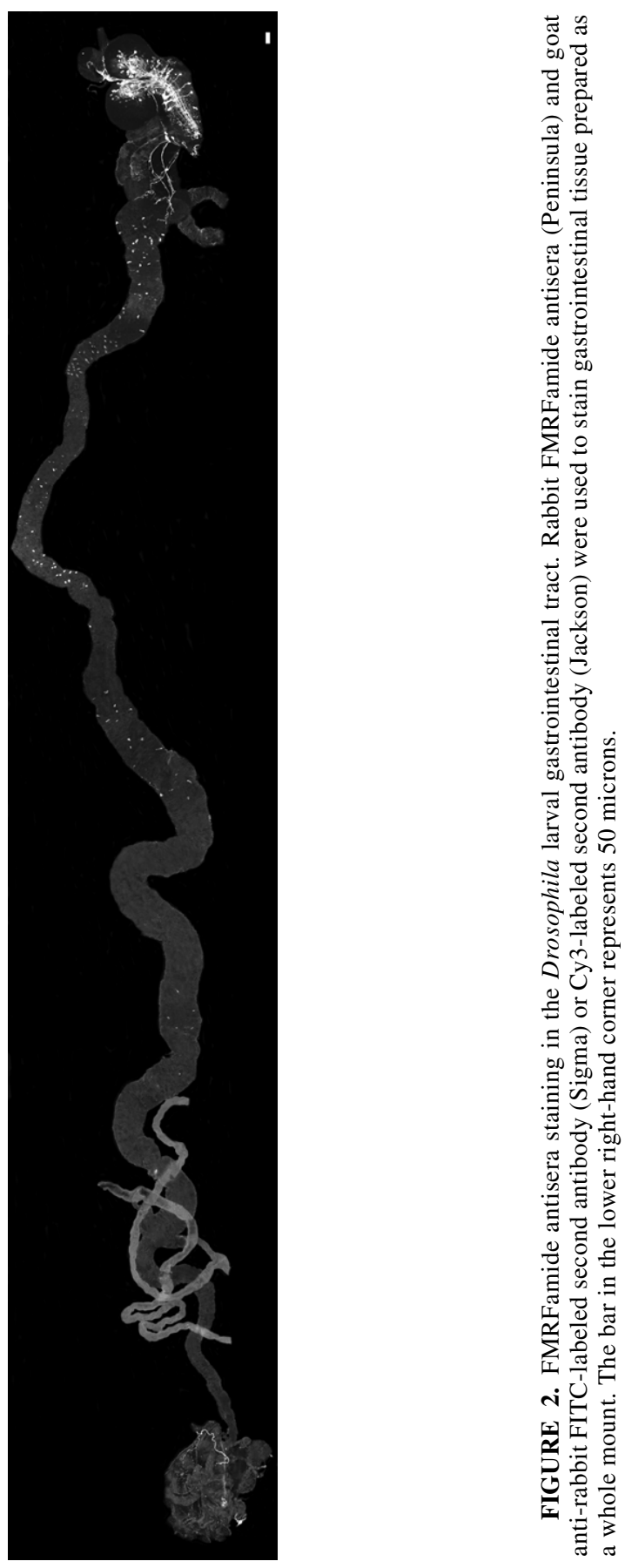
expression patterns of the known Drosophila FaRPs, TDVDHVFLRFamide (DMS), FDDYGHMRFamide (DSK I), and DPKQDFMRFamide, SDNFMRFamide, and TPAEDFMRFamide. ${ }^{9-13}$ Several cells in the brain, subesophageal ganglion, and ventral nerve cord contain FMRFamide immunoreactive material, but are not stained by any of the peptide-specific FaRP antisera. Thus, these data suggest that Drosophila neural tissue contains one or more novel FMRFamide-related peptides.

Based on Drosophila FaRP genomic sequences and on our immunolocalization data, we conclude that the unidentified peptides are not encoded by known genes. For instance, the Dms gene encodes only DMS; thus, it does not include the unidentified peptides. In addition to DSK I, the Dsk gene encodes DSK II and DSK 0; however, antisera to DSK I would recognize DSK II (GGDDQFDDYGHMRFamide), and DSK 0 (NQKTMSFamide) is recognized by FMRFamide antisera. SPKQDFMRFamide and PDNFMRFamide, although not isolated in our purification protocol, are encoded by the FMRFamide gene; however, our polyclonal antisera to DPKQDFMRFamide and antisera to SDNFMRFamide would recognize SPKQDFMRFamide and PDNFMRFamide, respectively.

While FMRFamide antisera stain Drosophila neural tissue consistently, there were two distinct levels of signal, one more intense than the other. The difference in intensities may be explained by the amount of material present, or the crossreactivity of the antigen and antisera. Our study did not address the basis for the differences in staining intensity observed.

The presence of FMRFamide immunoreactive material in the Drosophila gastrointestinal tract is represented by the staining of larval gut (FIgURE 2). Peptidespecific antisera have been used to determine the expression of individual Drosophila FaRPs in gut. TDVDHVFLRFamide is present in fibers that innervate the crop and in cell bodies of the rectum, ${ }^{9}$ and TPAEDFMRFamide immunoreactive material is present in several cells in the midgut. ${ }^{13}$ However, the identity of the material representing the FMRFamide-like immunoreactivity in the proventriculus and foregut is not known, and TPAEDFMRFamide immunoreactivity does not represent the entire staining pattern in the midgut. Thus, the total number of cells containing FMRFamide immunoreactive material is not accounted for by the expression of the known Drosophila FaRPs. Therefore, these data suggest that a novel FMRFamide-like material(s) is present in Drosophila gut.

FMRFamide-like immunoreactive materials are present in adult as well as early development. The complexity of FMRFamide antisera staining is retained during the life cycle of the animal as shown by the immunoreactivity in the adult central nervous system (FIgURE 3) and gastrointestinal system (FIgURE 4). Again, the cellular expression of the individual Drosophila FaRPs does not account for the complete staining pattern generated from FMRFamide antisera. ${ }^{9-13}$ Thus, these data indicate that one or more uncharacterized Drosophila FaRPs may exist.

Here, we show that FMRFamide immunoreactivity is present throughout development in the Drosophila central nervous system and gastrointestinal tract. The production of structurally related peptides in unique cellular distributions provides the animal with a powerful means to regulate the generation of numerous, novel messengers to modulate physiological activities. The widespread distribution and the large number of cells containing FaRPs during the life cycle of the animal support the conclusion that these peptides play several important roles in physiology. Our 
previous studies show that, for the most part, the expression patterns of individual FaRPs are not overlapping. ${ }^{9-13}$ For instance, DPKQDFMRFamide, SDNFMRFamide, and TPAEDFMRFamide encoded in the Drosophila FMRFamide gene are distributed in distinct cellular expression patterns and do not coexist. ${ }^{10,11,13,15}$ The

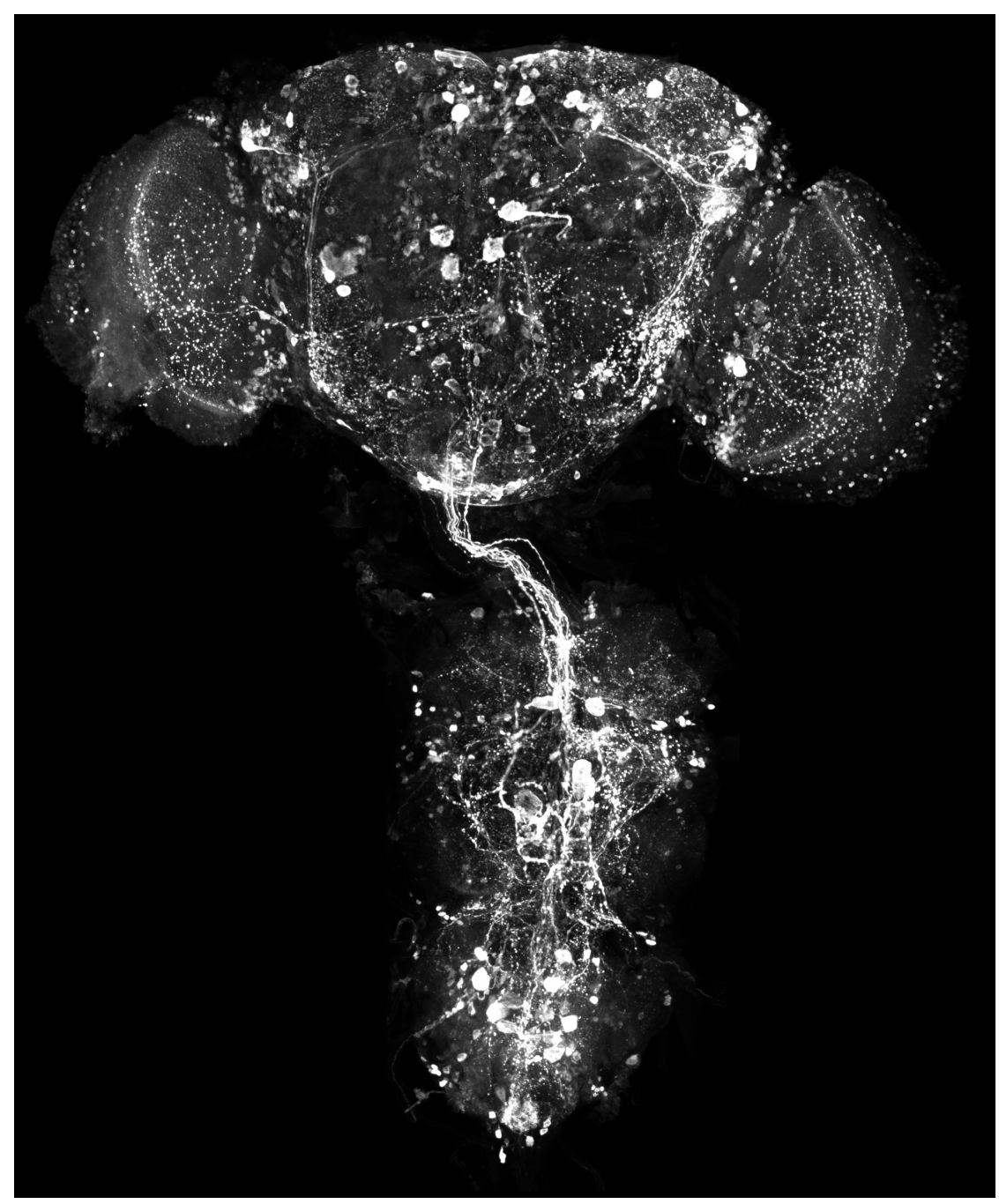

FIGURE 3. FMRFamide antisera staining in the Drosophila adult central nervous system. Rabbit FMRFamide antisera (Peninsula) and goat anti-rabbit FITC-labeled second antibody (Sigma) or Cy3-labeled second antibody (Jackson) were used to stain neural tissue prepared as a whole mount. 

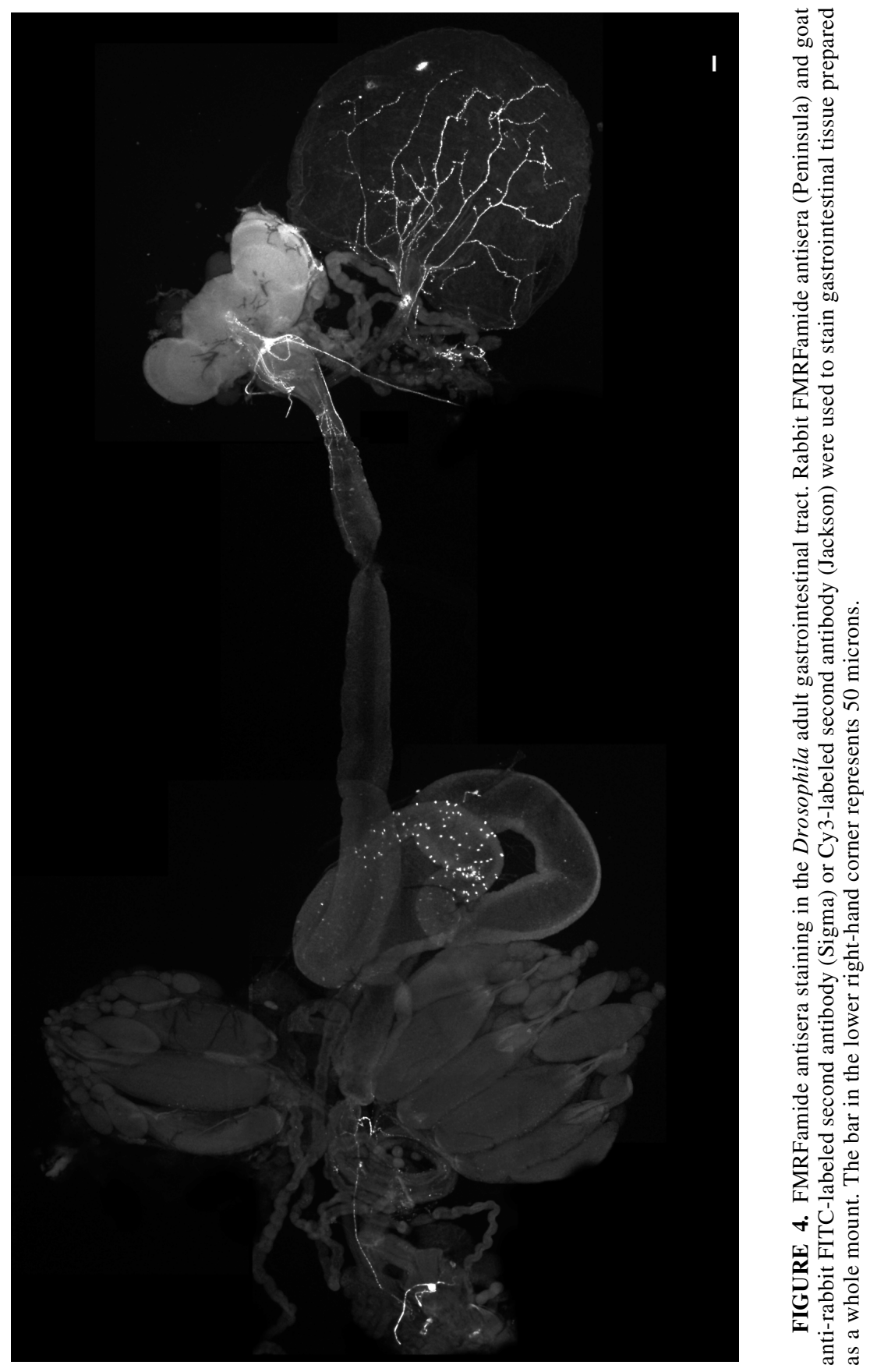
FaRPs, TDVDHVFLRFamide and FDDY(SO3H)GHMRFamide, encoded in the Drosophila Dms and Dsk genes, respectively, are not expressed in the same cells. ${ }^{16}$

Several conclusions can be made by comparing the expression of individual FaRPs and the distribution of FMRFamide immunoreactivity. Since the peptides are not expressed in the same cells, one conclusion is that there is not simple redundancy of function among the structurally related peptides. The peptides can affect similar tissues, but may receive unique regulatory cues due to the differences in cellular distribution. Indeed, the activities of Drosophila FaRPs are different. DMS acts as a neurotransmitter to regulate heart rate, while SDNFMRFamide modulates heart rate. ${ }^{14}$ In contrast, DPKQDFMRFamide and TPAEDFMRFamide do not affect heart rate. Another finding is that the FaRP polyprotein precursors undergo differential processing on a cell-specific level. ${ }^{9-13}$ In addition, our data support the hypothesis that one or more unidentified substances recognized by FMRFamide antisera are present in Drosophila neural and gut tissues.

\section{ACKNOWLEDGMENTS}

This research was supported by a National Science Foundation Grant (IBN No. 9724141) to R. Nichols.

\section{REFERENCES}

1. Price, D.A. \& M.J. Greenberg. 1977. Structure of a molluscan cardioexcitatory neuropeptide. Science 197: 670-672.

2. GreenberG, M.J. \& D.A. Price. 1992. Relationships among the FMRFamide-like peptides. Prog. Brain Res. 92: 25-37.

3. RAFFA, R.B. 1989. The action of FMRFamide (Phe-Met-Arg-Phe- $\mathrm{NH}_{2}$ ) and related peptides on mammals. Peptides 9: 915-922.

4. Nambu, J.R., C. Murphy-Erdosh, P.C. Andrews, G.J. Feistner \& R.H. Scheller. 1988. Isolation and characterization of a Drosophila neuropeptide gene. Neuron 1: $55-61$.

5. Nichols, R., S.A. Schneuwly \& J.E. Dixon. 1988. Identification and characterization of a Drosophila homologue to the vertebrate neuropeptide cholecystokinin. J. Biol. Chem. 263: 12167-12170.

6. Schneider, L.E. \& P.H. Taghert. 1988. Isolation and characterization of a Drosophila gene that encodes multiple neuropeptides related to FMRFamide. Proc. Natl. Acad. Sci. USA 85: 1993-1997.

7. NICHOLS, R. 1992. Isolation and structural characterization of Drosophila TDVDHVFLRFamide and FMRFamide-containing neural peptides. J. Mol. Neurosci. 3: 213-218.

8. Nichols, R. 1992. Isolation and expression of the Drosophila drosulfakinin neural peptide gene product, DSK-I. Mol. Cell. Neurosci. 3: 342-347.

9. McCormick, J. \& R. Nichols. 1993. Spatial and temporal expression identify dromyosuppressin as a brain-gut peptide in Drosophila melanogaster. J. Comp. Neurol. 338: 279-288.

10. Nichols, R., J. McCormick, I. Lim \& L. Caserta. 1995. Cellular expression of the Drosophila melanogaster FMRFamide neuropeptide gene product DPKQDFMRFamide. J. Mol. Neurosci. 6: 1-10.

11. Nichols, R., J. McCormick, I. Lim \& J. Starkman. 1995. Spatial and temporal analysis of the Drosophila FMRFamide neuropeptide gene product SDNFMRFamide: evidence for a restricted expression pattern. Neuropeptides 29: 205-213. 
12. Nichols, R. \& I. Lim. 1996. Spatial and temporal immunocytochemical analysis of drosulfakinin (Dsk) gene products in the Drosophila melanogaster central nervous system. Cell Tissue Res. 283: 107-116.

13. Nichols, R., J. McCoRmick \& I. Lim. 1999. Regulation of FMRFamide neuropeptide gene expression. J. Neurobiol. 39: 347-358.

14. Nichols, R., J. McCormick, I. Lim, M. Cohen, C. Jean, E. Howe, K. Paisley \& C. ROSARIO. 1999. Differential processing of neuropeptides influences Drosophila heart rate. J. Neurogenet. 13: 1-16.

15. McCormick, J., I. Lim \& R. Nichols. 1999. Neuropeptide precursor processing detected by triple immunolabeling. Cell Tissue Res. 297: 197-202.

16. Nichols, R., J. McCormick \& I. Lim. 1997. Multiple antigenic peptides designed to structurally-related Drosophila peptides. Peptides 18: 41-45.

17. Nichols, R., I. Lim \& J. MCCORMicK. 1999. Antisera to multiple antigenic peptides detect neuropeptide processing. Neuropeptides 33: 35-40. 